University of Wollongong

Research Online

Faculty of Engineering - Papers (Archive)

Faculty of Engineering and Information

Sciences

$15-3-2008$

\title{
2D and 3D Numerical Modeling of Combined Surcharge and Vacuum Preloading with Vertical Drains
}

Cholachat Rujikiatkamjorn

University of Wollongong, cholacha@uow.edu.au

Buddhima Indraratna

University of Wollongong, indra@uow.edu.au

J. Chu

Nanyang Technological University, Singapore

Follow this and additional works at: https://ro.uow.edu.au/engpapers

Part of the Engineering Commons

https://ro.uow.edu.au/engpapers/448

\section{Recommended Citation}

Rujikiatkamjorn, Cholachat; Indraratna, Buddhima; and Chu, J.: 2D and 3D Numerical Modeling of Combined Surcharge and Vacuum Preloading with Vertical Drains 2008.

https://ro.uow.edu.au/engpapers/448

Research Online is the open access institutional repository for the University of Wollongong. For further information contact the UOW Library: research-pubs@uow.edu.au 


\title{
2D AND 3D NUMERICAL MODELING OF COMBINED SURCHARGE AND VACUUM PRELOADING WITH VERTICAL DRAINS
}

\author{
Cholachat Rujikiatkamjorn \\ BEng (Hons), MEng (AIT), PhD \\ Research Associate, Civil Engineering Division, Faculty of Engineering, \\ University of Wollongong, Wollongong City, NSW 2522, Australia \\ Buddhima Indraratna \\ BSc (Hons., Lond.), MSc (Lond.), DIC, PhD (Alberta), FIEAust., FASCE, FGS \\ Professor of Civil Engineering, Faculty of Engineering, \\ University of Wollongong, Wollongong City, NSW 2522, Australia.

\begin{abstract}
Jian Chu
B Eng, $\mathrm{PhD}$

Associate Professor, School of Civil and Environmental Engineering, Nanyang Technological University, Block N1, 50 Nanyang Ave, Singapore 639798.
\end{abstract}

Submitted to: THE INTERNATIONAL JOURNAL OF GEOMECHANICS

GM/2007/000348

Author for correspondence:

Prof. B. Indraratna

Faculty of Engineering

University of Wollongong

Wollongong, NSW 2522

Australia.

Ph: +61242213046

Fax: +61242213238

Email: indra@uow.edu.au 


\title{
2D AND 3D NUMERICAL MODELING OF COMBINED SURCHARGE AND VACUUM PRELOADING WITH VERTICAL DRAINS
}

Cholachat.Rujikiakamjorn, Buddhima Indraratna, and Jian Chu

\begin{abstract}
This paper presents a three-dimensional (3D) and two-dimensional (2D) numerical analysis of a case study of a combined vacuum and surcharge preloading project for a storage yard at Tianjin Port, China. At this site, a vacuum pressure of $80 \mathrm{kPa}$ and a fill surcharge of $50 \mathrm{kPa}$ was applied on top of the $20 \mathrm{~m}$ thick soft soil layer through prefabricated vertical drains (PVD) to achieve the desired settlements and to avoid embankment instability. In 3D analysis, the actual shape of PVDs and their installation pattern with the in-situ soil parameters were simulated. In contrast, the validity of 2Dplane strain analysis using equivalent permeability and transformed unit cell geometry was examined. In both cases, the vacuum pressure along the drain length was assumed to be constant as substantiated by the field observations. The finite element code, ABAQUS, using the modified Cam-clay model was used in the numerical analysis. The predictions of settlement, pore water pressure and lateral displacement were compared with the available field data, and an acceptable agreement was achieved for both $2 \mathrm{D}$ and $3 \mathrm{D}$ numerical analyses. It is found that both $3 \mathrm{D}$ and equivalent $2 \mathrm{D}$ analyses give similar consolidation responses at the vertical cross section where the lateral strain along the longitudinal axis is zero. The influence of vacuum may extend more than $10 \mathrm{~m}$ from the embankment toe, where the lateral movement should be monitored carefully during the consolidation period to avoid any damage to adjacent structures.
\end{abstract}

Key words: consolidation, finite element analysis, plane strain method, soil improvement, vertical drains. 


\section{INTRODUCTION}

Due to the rapid increase in population in many countries, the construction activities have become concentrated in low-lying marshy areas and reclaimed lands, which are comprised of highly compressible weak organic and peaty soils of varying thickness. These soft deposits formed by peat or clay have very low bearing capacity and excessive settlement characteristics, affecting major infrastructure including buildings, roads and rail tracks (Holtz et al. 1991, Indraratna and Redana 2000). Therefore, it is necessary to stabilize the existing soft soils before commencing any construction activities in order to prevent excessive and differential settlements. The technique of installing prefabricated vertical drains (PVDs) combined with fill surcharge and vacuum preloading has been used to avoid the unfavourable stability issues relating to high surcharge embankments. The effectiveness of the PVDs combined with vacuum preloading has been discussed by Chu et al. (2000) and Chai et al. (2005). In this method, the vacuum head can be distributed to a greater depth of the subsoil using the PVD system. Also, consolidation period due to the stage construction can be minimized (Cognon et al., 1994; Shang et al., 1998; Yan and Chu, 2003).

In order to predict the behaviour of soft ground improved by PVDs, a unit cell theory representing a single drain enclosed by a soil within a cylindrical influence zone by assuming equal strain was proposed by Barron (1948) and Richart (1957). The single drain analysis cannot successfully predict the overall consolidation in a large project where hundreds of drains are installed. Single drain analysis with small strain condition can only be applied at the embankment centreline where the lateral displacements are zero. Elsewhere, towards the embankment toe, the single drain analysis becomes 
inaccurate due to the non-uniform surcharge load distribution, large strain cobditions, increased lateral yield, effects of changing embankment geometry and heave at the embankment toe (Indraratna et al., 1997).

Hird et al. (1992), Chai et al. (1995) and Indraratna et al. (2005) introduced an equivalent 2D plane strain approach to predict the soft clay behaviour improved by vertical drain system (Fig. 1). The embankment loading is considered as a strip load. This method can be conveniently simulated as a multi-drain system in numerical (FEM) modeling. Discrepancies between 2D predictions and observations, especially in terms of excess pore pressure and lateral displacments are often noted (Cheung 1991). Since the last decade, improved and user-friendly three-dimensional finite element (3D) codes have emerged as a powerful tool capable of capturing ground response details that cannot be analysed using traditional 2D (plane strain) finite element software (Small and Zhang, 1991). For 3D analysis, a single row of drains with influence zones has been considered, but without considering a smear zone (Cheung et al. 1991; Borges, 2004). This study demonstrates that a $3 \mathrm{D}$ analysis should be considered for embankments where the $2 \mathrm{D}$ plane strain condition may not be appropriate due to the nature of embankment geometry among the other reasons.

In this paper, a numerical analysis based on an equivalent plane strain finite element model proposed by Indraratna et al. (2005) is compared with a 3D finite element model for evaluating the performance of an embankment constructed on the reclaimed land at Tianjin port, China. At this site, a combined vacuum and surcharge load was employed to achieve the desired degree of consolidation. Two sections of the trial embankment with 
different aspect ratios (ratio of length to width of the embankment) were analysed using both 2D and 3D approaches. The effect of smear and vacuum pressure are incorporated in the numerical analysis. The uniformly distributing vacuum pressure over the soil surface and along the length of drains is assumed according to the field observations, and the predictions including settlements, excess pore pressures and lateral displacements are compared with the available field data. The advantages of controlling the excess pore pressure development and lateral displacement are also discussed in the paper.

GENERAL DESCRIPTION OF EMBANKMENT CHARACTERISTICS AND SITE CONDITIONS

Tianjin Port is approximately $100 \mathrm{~km}$ from Beijing, China, as reported by Chu and Yan (2005). Due to the rapid expansion of the port, construction of a new pier on reclamation land was required for a new storage facility. The site was reclaimed using clay slurry dredged from the seabed has formed the first top $3-4 \mathrm{~m}$ of the soil deposit. The soft muddy clay underneath the reclaimed soil was about $5 \mathrm{~m}$, followed by the soft muddy clay layer at a depth of $8.5-16 \mathrm{~m}$. A $6 \mathrm{~m}$ thick stiff silty clay underlies the soft muddy clay layer. The soil profile and its related soil properties are shown in Fig. 2, where the groundwater level is at the ground surface. The water contents of the soil layers are very close to or exceed their liquid limits, and the void ratio is in the range of $0.8-1.5$. The field vane tests indicate that the undrained shear strength varies from about 20 to $40 \mathrm{kPa}$. The coefficient of soil compressibilities determined by standard oedometer testing are between 0.89 and $1.07 \mathrm{MPa}^{-1}$. More description of the project can be found in Yan and Chu (2005). 
The storage facility occupies an area of $7500 \mathrm{~m}^{2}$. As the undrained shear strength of the top soft soil is very low, the vacuum preloading method was chosen to improve the soil. The required preloading pressure to achieve the desired settlement was approximately $140 \mathrm{kPa}$. The nominal vacuum pressure was $80 \mathrm{kPa}$. Therefore, a combined vacuum and fill surcharge preloading was used to improve the shear strength of the soil prior to construction. During construction, the site was divided into three sections, as shown in Fig. 3. Figure 4 presents the vertical cross-section and the locations of field instrumentation for Section II, which included the settlement gauges, pore water pressure transducers, multi-level gauges, inclinometers and piezometers. The settlement gauges were placed at various depths to measure differential subsurface settlements. The pore water pressure transducers were installed under the test embankment at $3 \mathrm{~m}$ deep intervals to a maximum depth of $16 \mathrm{~m}$. PVDs $(100 \mathrm{~mm} \times 3 \mathrm{~mm})$ with $20 \mathrm{~m}$ long were installed at $1 \mathrm{~m}$ spacing in a square pattern in all three sections. A $0.3 \mathrm{~m}$ sand blanket served as a platform for the PVDs installation and for placing the horizontal perforated pipes required for applying and distributing the vacuum pressure. The steal mandrel driven drains were installed using a static rig to minimise the extent of smearing as much as possible. The properties of drain are shown in Table 1. Horizontal drainage $(100 \mathrm{~mm}$ diameter corrugated pipes wrapped in geotextile filters) in transverse and longitudinal directions covered with impermeable membranes was laid to connect the PVDs to the vacuum pump. Within the scope of this paper, the results for the analysis of Sections II and III are presented. 


\section{THREE-DIMENSIONAL FINITE ELEMENT ANALYSIS}

A finite element program (ABAQUS v.6.5.1) coupled with Biot consolidation theory was employed to simulate the 3D multi-drain analysis (Hibbitt, Karlsson, and Sorensen, 2005). As the aspect ratio of Section II was $4(119 \mathrm{~m} / 30 \mathrm{~m})$, no deformation was expected along the length of Section II. Therefore, only half a row of vertical drains with their influence zone was simulated. The 3D finite element mesh consists of 90000 C3D8RP solid elements (8-node tri-linear displacement and pore pressure) (Fig. 5). No lateral displacement in y direction is assumed. In contrast, a quarter of the embankment area in Section III $\left(15 \times 25 \mathrm{~m}^{2}\right)$ was used in the model because of the two axes of symmetry and very low aspect ratio. The 3D finite element mesh consists of 101160 C3D8RP solid elements (Fig. 6). The four lateral displacement boundaries at $x=0, x=45 m, y=0$ and $y=34 \mathrm{~m}$ are assumed to be zero and are considered as impermeable boundaries. The displacement boundary at $\mathrm{z}=20 \mathrm{~m}$ is prescribed to be zero in all $\mathrm{x}, \mathrm{y}$ and $\mathrm{z}$ directions. A total of 350 individual band drains were created. To simulate the actual band drain boundary, the pore pressure was set along the $100 \mathrm{~mm}$ drain width to negative value for vacuum pressure. As observed by Indraratna and Rujikiatkamjorn (2004), the smear zone cross section area associated with the shape of mandrel can be considered as eliptic or rectangular in shape. In the analysis, a $150 \times 200 \mathrm{~mm}^{2}$ rectangular smear zone shape was employed to simplify the 3D mesh generation and to avoid the unfavorable mesh shape (Fig. 7). This area of the rectangular smear zone is equivalent to a circular $200 \mathrm{~mm}$ diameter smear zone or 2 times the equivalent diameter of the mandrel. According to the laboratory results discussed by Indraratna and Redana (1998) and Sathananthan and Indraratna (2006), the ratio of horizontal permeability in the undisturbed zone and 
horizontal permeability in the smear zone $\left(k_{h} / k_{s}\right)$ may vary from 1.5-2.0. However, this ratio can vary from 1.5 to 5 in the field, depending on the type of drain, the soil properties and the installation procedures (Bo et al. 2003). The well resistance was neglected due to the very high discharge capacity of the drain, i.e. $q_{w}>120 \mathrm{~m}^{3} / \mathrm{y}$ ear (Indraratna and Redana 2000).

\section{TWO-DIMENSIONAL PLANE STRAIN FINITE ELEMENT ANALYSIS}

To analyse the radial consolidation problem using a plane strain finite element analysis, the appropriate equivalence between the plane strain and true axisymmetric analysis must be established to obtain realistic predictions. Various conversion procedures have been proposed earlier (e.g. Shinsha et al. 1982; Hird et al. 1992; Bergado and Long 1994; Chai et al. 2001; Indraratna et al. 2005). Cheung et al. (1991) employed the conversion procedure which assumes that the settlement response at $50 \%$ degree of consolidation is the same for both 2D and axisymmetric (3D) conditions (Shinsha 1991). However, significant differences of the excess pore pressure predictions were found between these two schemes. In this study, the conversion method proposed by Indraratna et al. (2005) is adopted for the 2D plane strain analysis. In this approach, not only the entire degree of consolidation response for the equivalent $2 \mathrm{D}$ approach is the same as that of the $3 \mathrm{D}$ analysis, but also the smear zone was explicitly modelled. Even though, this equivalent method may increase the number of elements significantly in the FEM mesh, hence the computational time, the method still provides an acceptable accuracy for multi-drain analysis (Indraratna et al. 2004). 
Details of the permeability conversion for equivalent plane strain condition have been further refined to consider the vacuum consolidation by Indraratna et al (2005). A summary of the conversion from the axisymmetric to the equivalent plane strain model is presented below, for the benefit of the readers.

To obtain the same consolidation as the axisymmetric condition, the corresponding ratio of the smear zone permeability to the undisturbed zone permeability in plane strain analysis $\left(\frac{k_{s, p s}}{k_{h, p s}}\right)$ can be obtained by (Indraratna et al., 2005):

$$
\begin{aligned}
& \frac{k_{s, p s}}{k_{h, p s}}=\frac{\beta}{\frac{k_{h, p s}}{k_{h, a x}}\left[\ln \left(\frac{n}{s}\right)+\frac{k_{h, a x}}{k_{s, a x}} \ln (s)-\frac{3}{4}\right]-\alpha} \\
& \beta=\frac{2(s-1)}{n^{2}(n-1)}\left[n(n-s-1)+\frac{1}{3}\left(s^{2}+s+1\right)\right] \\
& \alpha=\frac{2}{3} \frac{(n-s)^{3}}{n^{2}(n-1)} \\
& s=d_{s} / d_{w} \\
& n=d_{e} / d_{w}
\end{aligned}
$$

where, $k_{s, a x}$ and $k_{h, a x}=$ horizontal soil permeability in the smear zone and in the undisturbed zone, respectively, in the axisymmetric configuration. $d_{e}=$ the diameter of soil cylinder dewatered by a drain, $d_{s}=$ the diameter of the smear zone, $d_{w}=$ the equivalent diameter of the drain,

By ignoring, both smear and well resistance effects, the simplified ratio of equivalent plane strain to axisymmetric permeability in the undisturbed zone can be attained as: 


$$
\frac{k_{h, p s}}{k_{h, a x}}=\frac{0.67 \frac{(n-1)^{2}}{n^{2}}}{\left[\ln (n)-\frac{3}{4}\right]}
$$

An equivalent vacuum pressure can now be expressed by:

$$
p_{0, p s}=p_{0, a x}
$$

The equivalent plane strain model with vacuum application (Equations 1-3) was incorporated into the finite element code (ABAQUS) employing the modified Cam-Clay model (Roscoe and Burland, 1968). Rujikiatkamjorn et al. (2007) have analysed Section II under plane strain condition. The results will be used in comparison with 3D analysis. For Section III, 2 Cases representing 2 sections along $\mathrm{x}=0$ plane (2D Case A) and $\mathrm{y}=0$ plane (2D Case B). (i.e. along the lines of embankment symmetry) were analysed (Fig. 8). The 2D finite element mesh consisted of 14400 and 18400 C2D8RP solid elements (8-node displacement and pore pressure), respectively. Only one-half of the embankment was simulated in the model because of the symmetry. The left and right boundaries are assumed as zero lateral displacement boundaries. The displacement boundary at the bottom is prescribed to be zero in all directions, and the bottom and right boundaries are assumed impermeable. The smear zone width $\left(2 b_{s}\right)$ was taken approximately $200 \mathrm{~mm}$ (Fig. 9). The vacuum pressure was specified by the negative pore pressure boundaries along the length of the drains. 


\section{SOIL PARAMETERS AND SIMULATION OF VACUUM AND EMBANKMENT}

\section{LOADING}

Surcharge load was simulated using incremental vertical loads to the upper boundary (see Fig. 8). The effect of embankment stiffness and lateral earth pressure influenced by the embankment fill can be ignored when the stiffness ratio between the embankment fill (silty clay) and the soil foundation is less than 100 (Perloff 1975). Zhang (1999) showed that a very stiff embankment would induce smaller shear stresses near embankment toe and the maximum shear stress location may move closer to the embankment centreline. This method tends to yield more lateral displacement (Tavenas et al 1979).

The relevant soil parameters of 4 subsoil layers for 2D and 3D analysis are summarised in Table 2. The soil permeability used in 2D analysis was determined from Eqs. (1) and (2). The critical-state soil properties tabulated here were determined based on triaxial testing and standard oedometer testing, and. references to Hou et al. (1987) were made in the determination of the modified Cam-clay parameters $\lambda, \kappa, \gamma$ and $\mathrm{k}$. At this site, a vacuum pump capable of generating a suction of $80 \mathrm{kPa}$ was used. The pore pressure reduction was calculated based on the difference between the measured pore pressure and the initial hydrostatic pore pressure. It was observed that the reduction of pore pressure at the final stage was almost the same as the applied suction along the entire depth of PVDs $(-80 \mathrm{kPa})$. Therefore, the vacuum pressure was assumed to be constant along the drain elements and the soil surface. 
Some settlements occurred after the vertical drains were installed, but before the vacuum and surcharge loads were applied. A month had elapsed between the installation of vertical drains and the application of vacuum loads. The ground settlements measured before the application of vacuum loads was 0.31 and $0.25 \mathrm{~m}$ for Sections II and III, respectively. The settlements were induced mainly due to the dissipation of the existing excess pore water pressures in the reclaimed soil layer. The disturbance caused by the installation of the vertical drains may have also contributed to the settlement. It is noted that the analysis only considers the consolidation period after the application of vacuum pressure. The field data has been adjusted for the small settlement observed earlier. After approximately 30-40 days of the vacuum application, the embankment was raised to provide the additional surcharge pressure of 50 and $60 \mathrm{kPa}$ for Sections II and III, respectively. The average unit weight of the surcharge fill was about $17 \mathrm{kN} / \mathrm{m}^{3}$. The loading stages for Sections II and III, including the vacuum pressure measured are illustrated in Fig. 10, where Figure 10b shows that the measured vacuum pressure under the membrane is almost constant at this site. This verifies the efficiency of the vacuum system. The settlement and excess pore water pressure were recorded for about 120 days.

\section{NUMERICAL RESULTS AND THEIR COMPARISON WITH FIELD DATA}

In this section, the predictions based on the $3 \mathrm{D}$ and equivalent $2 \mathrm{D}$ plane strain finite element analyses are compared with the field measurements. Figures 11 and 12 show a comparison between the predicted and recorded field settlements at the centreline of the embankment together with the loading history for Sections II and III, respectively. As expected, the predicted settlements agree with the field data. The surface settlement profiles at 180th day for Section III are shown on Fig. 13 along $x=0$ and $y=0$ planes (ref. 
Fig. 8) in comparison with the 2D analysis (Cases A and B). The surface settlement predictions from 3D and 2D analyses are almost the same. There is no heave obtained from the predictions due to the favourable effect of vacuum pressure. In the plane strain (2D model), strains in the longitudinal direction are considered zero, hence it is normal that strains will increase in the z-direction to keep the same volumetric change. The average volume of the water per drain extracted from the soil was $1.6 \mathrm{~m}^{3} / \mathrm{drain}$ as computed by the 3D analysis. This value depends not only on the discharge capacity of the drain, but also the soil properties in the smear and undisturbed zones.

The comparison of predicted and measured excess pore water pressure variation with time, at the depths of $5.5 \mathrm{~m}$ and $11 \mathrm{~m}, 0.25 \mathrm{~m}$ away from the embankment centreline (Section II) is illustrated in Fig. 14. The effect of surcharge loading can be observed by the shift of the time-dependent pore pressure (indicated by arrows in Fig. 14). The predicted pore pressures from 3D FEM are almost the same as 2D FEM and agree well with the measured results. The variation of pore pressure reduction with depth is illustrated in Fig. 15. It can be seen that the assumption of constant vacuum pressure along the drain length is justified. The variation of pore pressure with depth can be due to the soil permeability. As there is no piezometer installed in Section III, the comparison of predicted results from 2D and 3D are shown in Fig. 16a. It can be seen that pore pressures reduction obtained from 2D are more than that from 3D DEM analyses during the initial 60 days. The pore pressure reduction becomes constant $(-80 \mathrm{kPa})$ after about 120 days. The pore pressure contours after 168 days is illustrated in Fig. 16b. The effect of vacuum application (negative pore pressure) can extend to about $2-3 \mathrm{~m}$ from the 
embankment border. Figure $17 \mathrm{~b}$ represents the distribution of pore pressure reduction at a depth of $2 \mathrm{~m}$ as shown in Fig. $17 \mathrm{a}$ at time $=50$ days. In the $3 \mathrm{D}$ analysis, the pore pressure profiles at $\mathrm{y}=0.5 \mathrm{~m}$ (along a row of PVD) and at $\mathrm{y}=0 \mathrm{~m}$ (at the centreline between rows of PVDs) are plotted together with the results of the 2D analysis (Case B). It can be seen that pore pressure across PVD row drops significantly to $-80 \mathrm{kPa}$ (applied vacuum pressure) when approaching the drain boundaries (Fig. 17c) for both 2D and 3D analyses (at $\mathrm{y}=0.5 \mathrm{~m}$ ). The pore pressure reductions along the centreline between the rows of PVDs are almost constant due to the absence of drain boundaries. Realistic results cannot be obtained from the equivalent plane strain analysis due to the infinite length of the drain wall.

Figure 18a illustrates the comparison between the measured and predicted lateral movements at the toe of the embankment (Section II) after 5.5 months. The negative lateral displacement denotes an inward soil movement towards the centreline of the embankment. The predictions from 2D and 3D agree well with the measured data. The lateral displacement predictions from 2D and 3D analysis for Section III are almost the same along both centrelines of the embankment ( $\mathrm{x}$ and $\mathrm{y}$ directions) (Fig. 18b). The 3D analysis shows that the lateral displacements vary towards the embankment toe (Fig. 19). This could not be captured by plane strain analysis. It can be seen from the 3D analysis that the inward lateral displacement (negative values) is maximum along the embankment centreline (i.e. $x=0$ and $y=0$ ) and continually decreases towards the embankment corner. This zone may be prone to failure by tension. The 3D analysis suggests that the effect of vacuum application (negative movements) may extend more than $10 \mathrm{~m}$ from the edge of 
the embankment, if only the vacuum pressure is applied (i.e. no fill surcharge). The inward lateral movement zone may be reduced using the surcharge loading. The technique of distributing the vacuum head along the drain length and along the surface in the numerical analysis has greater advantages than simply increasing the equivalent surcharge. This is because the correct prediction of negative excess pore pressure along the drain length and associated inward lateral movements represent the true field conditions of vacuum consolidation. It is shown that section along the half length of the embankment which has an aspect ratio more than 1.8 can still be analysed under plane strain condition.

In general, results obtained from the three-dimensional and two-dimensional approach based on the permeability conversion proposed by Indraratna et al. (2005) are only slightly different to each other. In this method, the entire average degree of consolidation curve obtained from the equivalent $2 \mathrm{D}$ condition is the same as that of the $3 \mathrm{D}$ condition, thereby reducing the resulting differences of pore pressure and lateral displacement predictions as long as plane strain condition can be justified (i.e. at the half length of the embankment). In this context, it appears that the equivalent plane strain analysis based on an appropriate conversion technique can be applied with confidence, rather than having to always depend on a time-consuming three-dimensional analysis.

\section{CONCLUSIONS}

In this paper, a three-dimensional and two-dimensional multi-drain finite element analyses (ABAQUS) were executed to evaluate the consolidation of soil under combined 
vacuum and surcharge (fill) loading. In the 3D analysis, the actual embankment geometry with individual band drains surrounded by an assumed rectangular smear zone was considered. In the 2-D plane strain analysis, the conversion method proposed by Indraratna et al. (2005) was employed to determine the equivalent permeability coefficients in the smear and undisturbed zones for each of the sub soil layer. The modified Cam-clay theory was adopted as the appropriate soil constitutive model in the finite element analysis. Rather than increasing the conventional surcharge load by an equivalent vacuum head, the use of a constant vacuum pressure at the soil surface and along the drain length was found to be appropriate for determining the settlements and excess pore water pressures at different depths, and for predicting the lateral movements. These numerical predictions obtained from both 2D and 3D analyses compared well with the field measurements.

The sets of results from equivalent $2 \mathrm{D}$ and $3 \mathrm{D}$ analyses were very similar, in terms of settlements, excess pore pressures and lateral displacements. It is shown that the equivalent plane strain (i.e. 2D) analysis is sufficient from a computational point of view, especially in the case of a multi-drain analysis of large projects where the 2-D plane strain application is more convenient. From a practical point of view, the height of surcharge fill can be reduced with the application of vacuum preloading to achieve the same desired rate of consolidation. The application of surcharge pressure after the initial vacuum preloading could be used to reduce the inward lateral movement near the embankment toe, thus avoiding potential damage to adjacent utilities or structures up to $10 \mathrm{~m}$ away from the embankment toe. 


\section{REFERENCES}

Barron, R. A. 1948. The influence of drain wells on the consolidation of fine-grained soils. Diss., Providence, U S Eng. Office.

Bergado, D.T. and Long, P.V. 1994. Numerical analysis of embankment on subsiding ground improved by vertical drains and granular piles. Proc. 13th ICSMFE, New Delhi, India, pp. 1361-1366.

Bo, M. W., Chu, J., Low, B. K., and Choa, V. 2003. Soil improvement; prefabricated vertical drain techniques, Thomson Learning, Singapore.

Borges, J.L. 2004. Three-dimensional analysis of embankments on soft soils incorporating vertical drains by finite element method, Computers and Geotechnics, 31:665-676.

Chai, J.C., Carter, J.P., and Hayashi, S. 2005. Ground deformation induced by vacuum consolidation. Journal of Geotechnical and Geoenvironmental Engineering, 131(12):1552-1561.

Chai, J.C., Shen, S.L., Miura, N. and Bergado, D.T. 2001. Simple method of modelling PVD improved subsoil. J. of Geotechnical Engineering, ASCE, 127(11): 965-972.

Chai, J. C., Miura, N., Sakajo, S. and Bergado, D. 1995. Behavior of vertical drain improved subsoil under embankment loading. J. Soil and Foundations, Japanese Geotechnical Society, 35(4): 49-61.

Cheung, Y. K., Lee, P. K. K. and Xie, K. H. 1991. Some remarks on two and three dimensional consolidation analysis of sand-drained ground. J. Computer and Geotechnics, Elsevier Sci. Publishers Ltd, England (GB), 12: 73-87. 
Chu, J. and Yan, S. W. (2005). Estimation of degree of consolidation for vacuum preloading projects. International Journal of Geomechanics, ASCE, 5(2): 158165.

Chu, J. Yan, S.W., and Yang, H. 2000. Soil improvement by the vacuum preloading method for an oil storage station. Geotechnique, 50(6): 625-632.

Cognon, J. M., Juran, I., and Thevanayagam, S. 1994. Vacuum consolidation technologyprinciples and field experience. In Proceedings of conference on vertical and horizontal deformations of foundations and embankments deformations, College station, Texas. pp. 1237-1248.

Hibbitt, Karlsson, and Sorensen 2006. ABAQUS/Standard User's Manual, Published by HKS Inc.

Hird, C.C., Pyrah, I.C. and Russell, D. 1992. Finite element modelling of vertical drains beneath embankments on soft ground. Geotechnique, 42(3), pp. 499-511.

Hird, C.C., Pyrah, I.C., Russell, D. and Cinicioglu, F. 1995. Modeling the effect of vertical drains in two-dimensional finite element analyses of embankments on soft ground. Can. Geotech. J., 32: 795-807.

Holtz, R.D., Jamiolkowski, M., Lancellotta, R. and Pedroni, S. 1991. Prefabricated vertical drains: design and performance, CIRIA ground engineering report: ground improvement. Butterworth-Heinemann Ltd, UK, 131 p.

Hou, Z., Chen, H. and Qian, Z. 1987. Tianjin Soft Soil Foundation, Tianjin Science and Technology Publishing House (in Chinese). 
Indraratna, B., and Redana, I.W. 2000 Numerical modeling of vertical drains with smear and well resistance installed in soft clay. Canadian Geotechnical Journal, 37: 133145.

Indraratna, B., and Redana, I. W. 1998. Laboratory determination of smear zone due to vertical drain installation. J. Geotech. Eng., ASCE, 125(1): 96-99.

Indraratna, B., and Rujikiatkamjorn C., 2004. Laboratory Determination of Efficiency of Prefabricated Vertical Drains Incorporating Vacuum Preloading. The 15th Southeast Asian Geotechnical Conference. Bangkok, Thailand, Vol. 1, 453-456.

Indraratna, B., Bamunawita, C., and Khabbaz, H. 2004. Numerical modeling of vacuum preloading and field applications. Canadian Geotechnical Journal, 41: 1098-1110.

Indraratna, B., Sathananthan, I., Rujikiatkamjorn C. and Balasubramaniam, A. S. 2005. Analytical and numerical modelling of soft soil stabilized by PVD incorporating vacuum preloading. International Journal of Geomechanics, 5(2). 114-124.

Perloff, W.H. 1975. Pressure distribution and settlement. In Foundation engineering handbook. Edited by H.F. Winterkorn and H.Y. Fang. Van Nostrand Reinhold Company, New York, pp. 148-196.

Richart, F.E. 1957. A review of the theories for sand drains. Journal of the Soil Mechanics and Foundations Division, ASCE, 83(3): 1-38.

Rujikiatkamjorn C., Indraratna, B. and Chu, J. (2007). Numerical modelling of soft soil stabilized by vertical drains, combining surcharge and vacuum preloading for a storage yard. Canadian Geotechnical Journal, (in press). 
Sathananthan, I. and Indraratna, B. 2006. Laboratory Evaluation of Smear Zone and Correlation between Permeability and Moisture Content. Submitted to Journal of Geotechnical and Geoenvironmental Engineering, ASCE 132(7), 942-945.

Small J. and Zliang B (1991) Consolidation of clays subjected to three dimensional embankment loadings. International Journal for Numerical and Analytical Methods in Geomechanics, 15(12): 857-870.

Shang, J.Q., Tang, M., and Miao, Z. 1998. Vacuum preloading consolidation of reclaimed land: a case study. Canadian Geotechnical Journal, 35: 740-749.

Shinsha, H., Hara, H., Abe, T. and Tanaka, A. 1982. Consolidation settlement and lateral displacement of soft ground improved by sand-drains. Tsushi-to-Kiso. Japan Society Soil Mech. Found. Eng., 30(2): 7-12.

Tavenas, F.A., Mieussens, C., and Bourges, F. 1979. Lateral displacements in clay foundations under embankments. Canadian Geotechnical Journal, 16(3): 532-550.

Yan, S.W. and Chu, J. 2003. Soil improvement for a road using a vacuum preloading method. Ground Improvement, 7(4): 165-172.

Zhang, L.M 1999. Settlement patterns of soft soil foundations under embankments. Canadian Geotechnical Journal, 36(4), 774-781. 


\section{List of Tables}

Table $1 \quad$ Vertical drain parameters

Table 2 Selected soil parameters in 2D and 3D FEM analysis 


\section{List of Figures}

Figure 1 PVDs configuration (a) three dimensional condition (square pattern), (b) equivalent plane strain condition

Figure 2 Soil properties and profile at Tianjin port (adopted from Yan and Chu, 2003)

Figure 3 Field instrumentation plan for the trial embankments at Tianjin Port (adopted from Yan and Chu, 2003)

Figure 4 Vertical cross section A-A and locations of fieldinstruments

Figure 5 3D Finite element mesh for Section II (a) C3D8RP element and (b) isometric view

Figure 6 3D Finite element mesh for Section III (a) isometric view and (b) top view Figure 7 A sigle band drain surrouding smear zone for 3D analysis

Figure 8 2D Finite element mesh for Section III (a) $\mathrm{x}=0$ plane, (2D Case A) (b) $\mathrm{y}=0$ plane, (2D Case B)

Figure 9 A drain wall with smear zone for 2D analysis

Figure 10 Staged loading history and the measured vacuum pressure

Figure 11 Section II (a) Loading history and (b) Consolidation settlements

Figure 12 Section III (a) Loading history and (b) Consolidation settlements

Figure 13 Surface settlement profiles at 180th day (Section III)

Figure 14 Pore pressure variation at $0.25 \mathrm{~m}$ away from the embankment centreline (Section II): (a) 5.5m depth and (b) 11.0m depth (arrows indicate tiems when surcharge loads were applied)

Figure 15 Pore pressure reduction with depth (Section II) 
Figure 16 Pore pressure variation (Section III) at $0.25 \mathrm{~m}$ away from the embankment centreline at $5.5 \mathrm{~m}$ depth (arrows indicate tiems when surcharge loads were applied)

Figure 17 Distribution of pore pressure reduction (Section III) at 50th day (a) 3D vertical cross-section representing locations of consideration b) $35 \mathrm{~m}$ from the embankment centreline and (c) $5 \mathrm{~m}$ from the embankment centreline

Figure 18 Lateral displacments at embankment toe (a) Section II at $168^{\text {th }}$ day and (b) Section III at $180^{\text {th }}$ day

Figure 19 Surface horizontal displacement contours after 180 days (Section III) (a) horizontal displacement in y direction $\left(\mathrm{u}_{\mathrm{y}}\right)$ and $(\mathrm{b})$ horizontal displacment in $\mathrm{x}$ direction $\left(\mathrm{u}_{\mathrm{x}}\right)$ 
Table 1. Vertical drain parameters

\begin{tabular}{l|l}
\hline \hline Spacing, $S$ & $1.0 \mathrm{~m}$ (square) \\
Length of vertical drain & $20 \mathrm{~m}$ \\
Dimension of drain & $100 \times 3 \mathrm{~mm}^{2}$ \\
Discharge capacity, $q_{w}$ & $100 \mathrm{~m}^{3} /$ year (per drain) \\
Dimension of mandrel & $120 \times 50 \mathrm{~mm}^{2}$ \\
\hline \hline
\end{tabular}


Table 2. Selected soil parameters in 2D and 3D FEM analysis

\begin{tabular}{|c|c|c|c|c|c|c|c|c|c|c|c|}
\hline \multirow{3}{*}{$\begin{array}{l}\text { Depth } \\
\text { (m) }\end{array}$} & \multirow{3}{*}{$\lambda$} & \multirow{3}{*}{$\kappa$} & \multirow{3}{*}{$v$} & \multirow{3}{*}{$e_{0}$} & \multirow{3}{*}{$\begin{array}{c}\gamma \\
\mathrm{kN} / \mathrm{m}^{3}\end{array}$} & \multirow{2}{*}{$\begin{array}{c}k_{v} \\
10^{-10}\end{array}$} & \multirow{2}{*}{$\begin{array}{l}k_{h, a x} \\
10^{-10}\end{array}$} & \multirow{2}{*}{$\begin{array}{l}k_{s, a x} \\
10^{-10}\end{array}$} & \multirow{2}{*}{$\begin{array}{l}k_{h, p s} \\
10^{-10}\end{array}$} & \multirow{2}{*}{$\begin{array}{l}k_{s, p s} \\
10^{-10}\end{array}$} & \multirow[t]{3}{*}{ OCR } \\
\hline & & & & & & & & & & & \\
\hline & & & & & & $\mathrm{m} / \mathrm{s}$ & $\mathrm{m} / \mathrm{s}$ & $\mathrm{m} / \mathrm{s}$ & $\mathrm{m} / \mathrm{s}$ & $\mathrm{m} / \mathrm{s}$ & \\
\hline $0.0-3.5$ & 0.12 & 0.03 & 0.3 & 1.1 & 18.3 & 6.67 & 20 & 6.67 & 5.91 & 1.46 & $1-1.1$ \\
\hline $3.5-8.5$ & 0.14 & 0.03 & 0.25 & 1.0 & 18.8 & 13.3 & 40 & 13.3 & 11.8 & 2.92 & $1.2-1.5$ \\
\hline $8.5-16.0$ & 0.20 & 0.04 & 0.3 & 1.35 & 17.5 & 6.67 & 20 & 6.67 & 5.91 & 1.46 & $1.2-1.6$ \\
\hline $16.0-20.0$ & 0.10 & 0.02 & 0.27 & 0.9 & 18.5 & 1.67 & 5 & 1.67 & 1.48 & 0.365 & $1.1-1.4$ \\
\hline
\end{tabular}

Note: $\kappa \quad$ Slope of normal consolidation curve for unloading stage

$\lambda \quad$ Slope of normal consolidation curve for loading stage after preconsolidation pressure

$v \quad$ Poisson's ratio in terms of effective stress at in-situ effective stress

$\gamma_{\mathrm{w}} \quad$ Unit weight of soil

OCR Overconsolidation ratio 


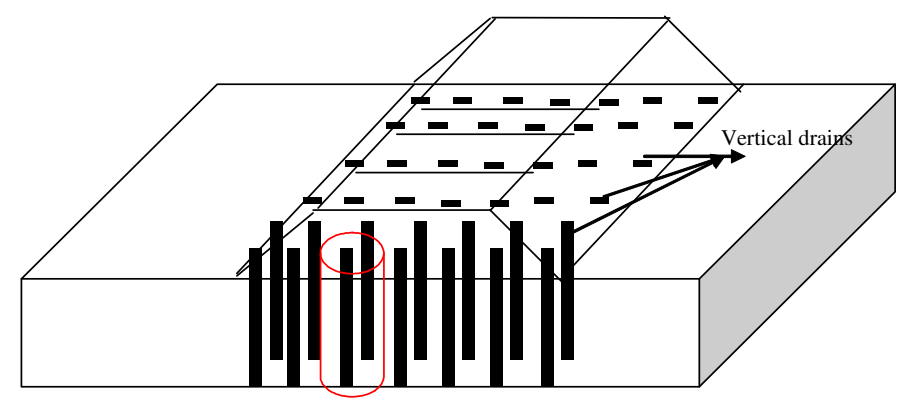

(a)

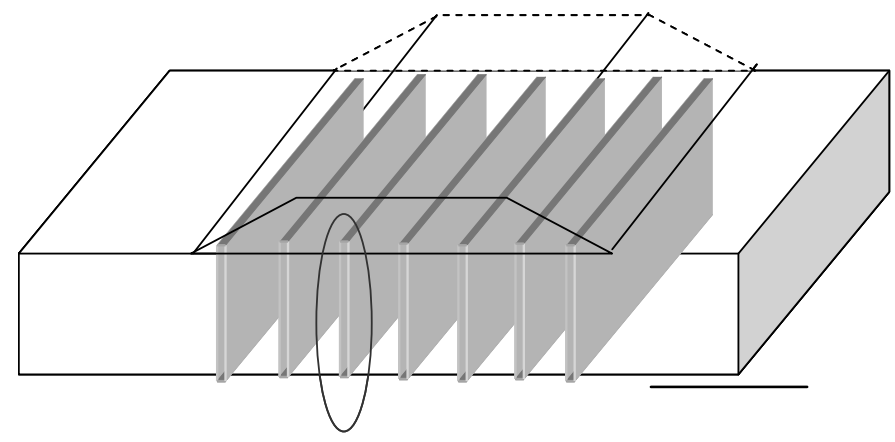

(b)

Figure 1 PVDs configuration (a) three dimensional condition (square pattern), (b) equivalent plane strain condition 


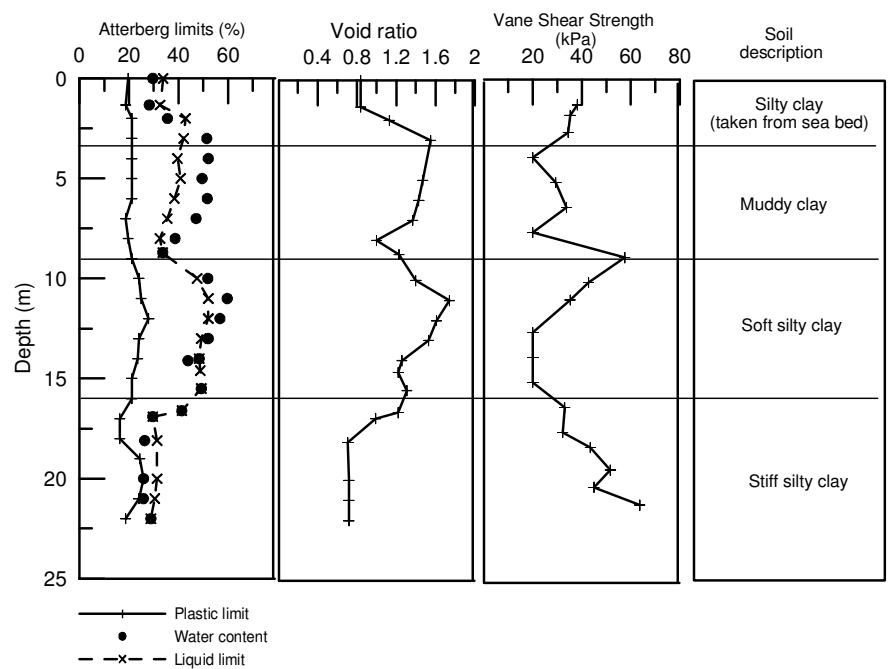

Figure 2 Soil properties and profile at Tianjin port (adopted from Yan and Chu, 2003) 


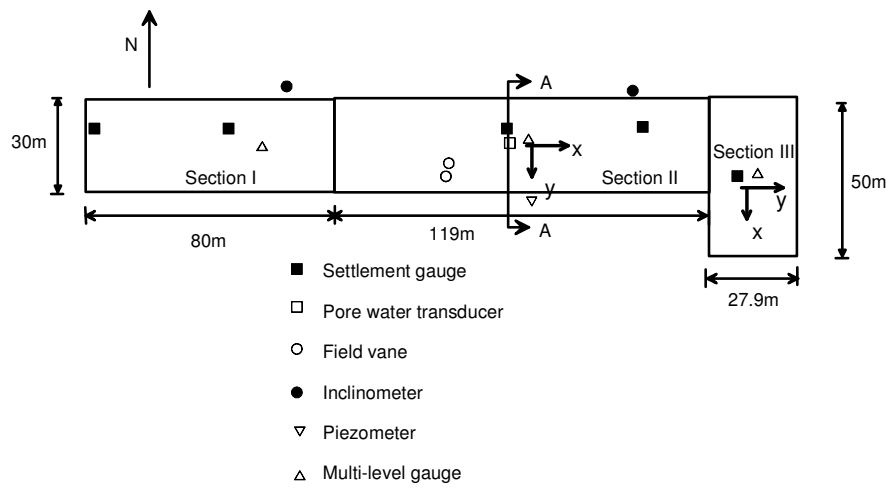

Figure 3 Field instrumentation plan for the trial embankments at Tianjin Port (adopted from Yan and Chu, 2003) 


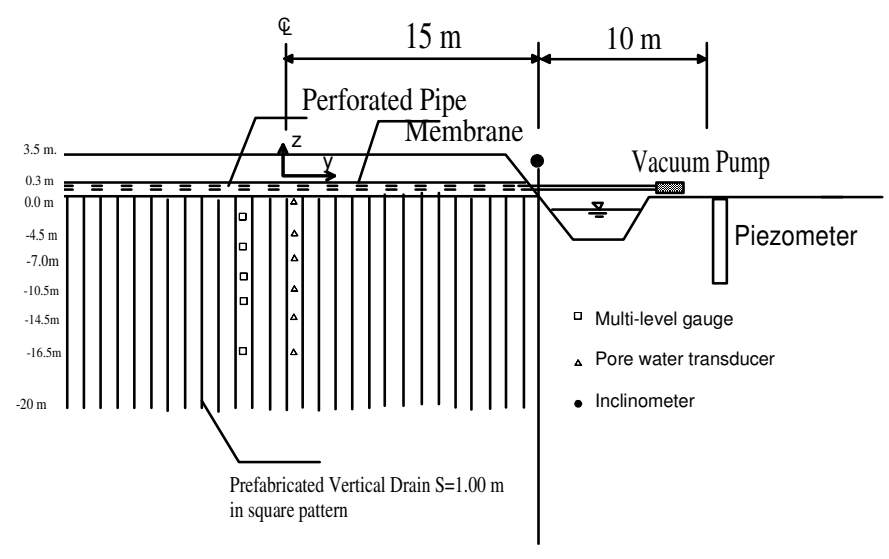

Figure 4 Vertical cross section A-A and locations of fieldinstruments 


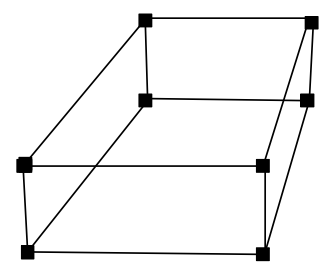

- Displacement and pore pressure node

(a)

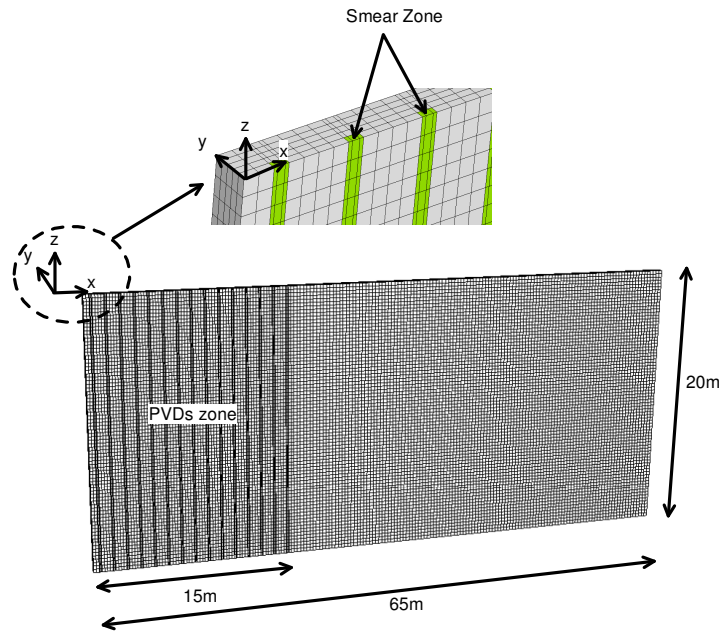

(b)

Figure 5 3D Finite element mesh for Section II (a) C3D8RP element and (b) isometric view 


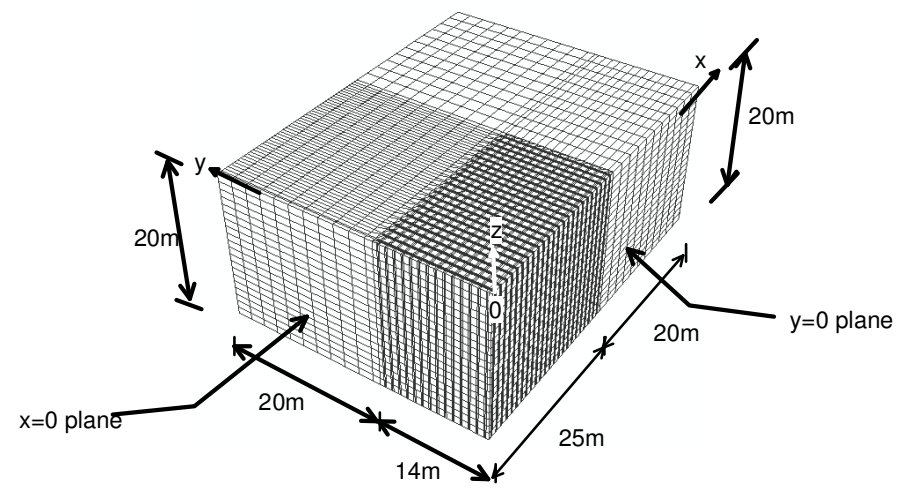

(a)

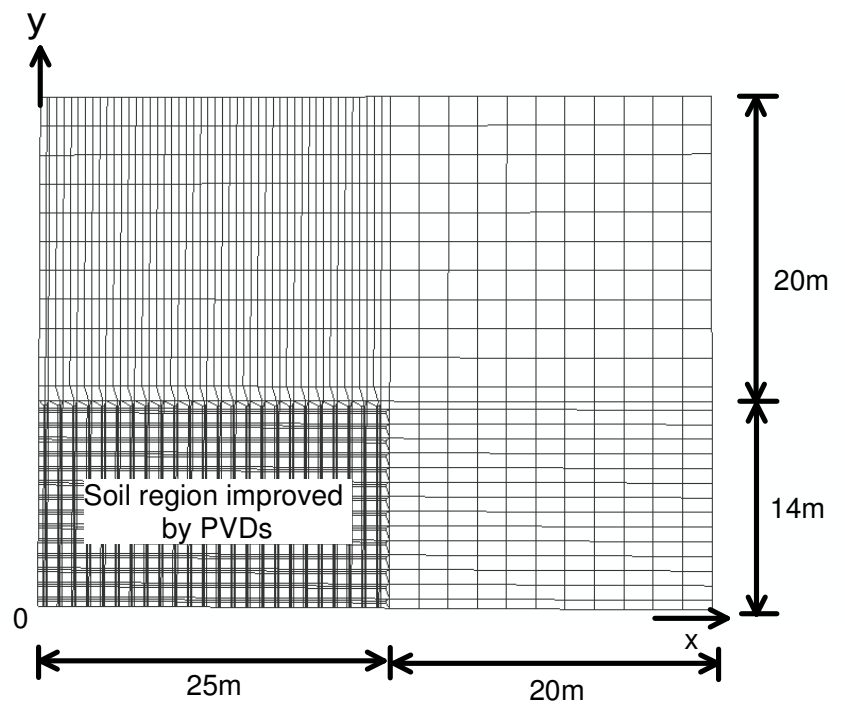

(b)

Figure 6 3D Finite element mesh for Section III (a) isometric view and (b) top view 


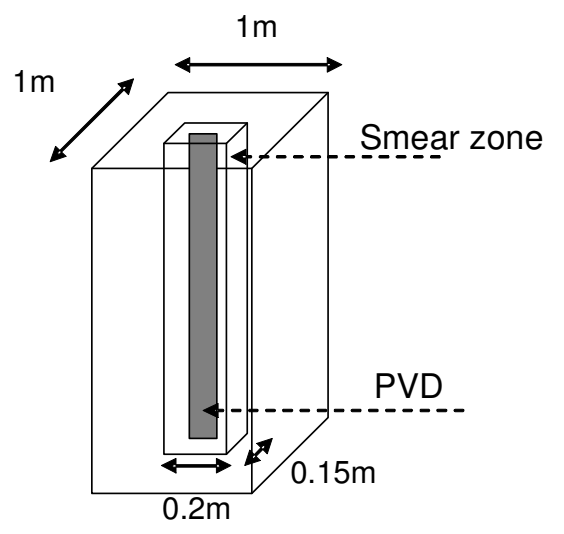

Figure 7 A sigle band drain surrouding smear zone for 3D analysis 


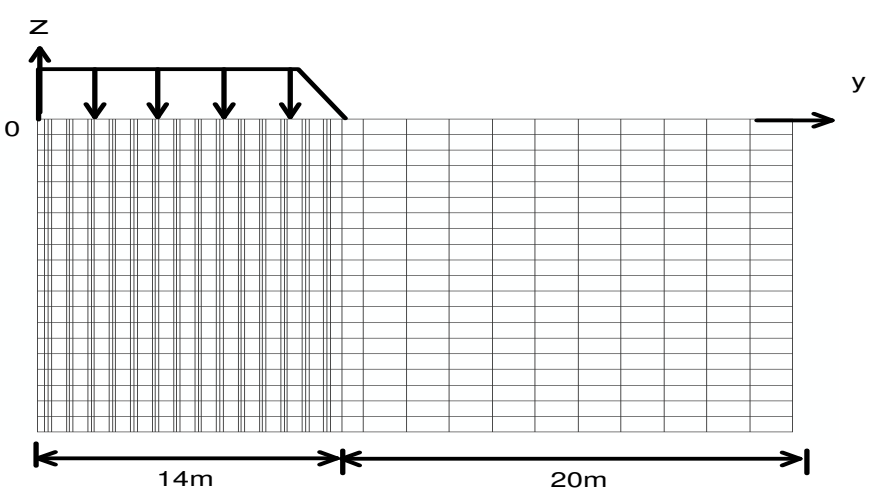

(a)

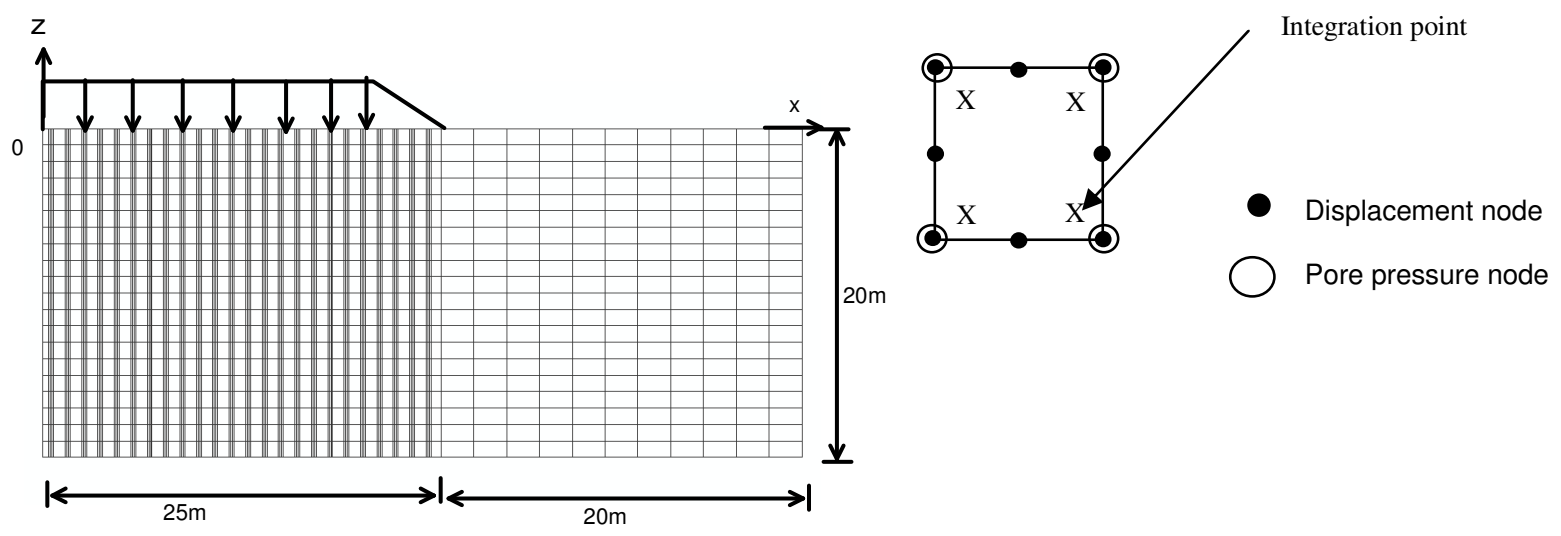

(b)

Figure 8 2D Finite element mesh for Section III (a) $\mathrm{x}=0$ plane, (2D Case A) (b) $y=0$ plane, (2D Case B) 


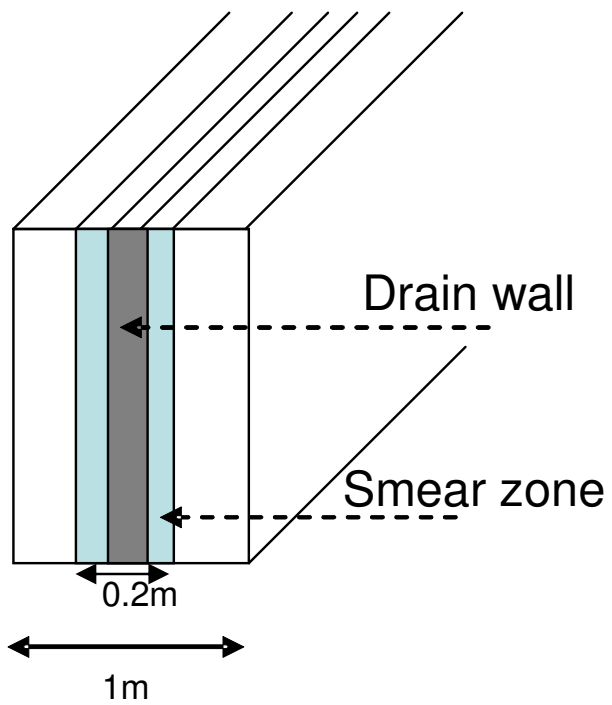

Figure 9 A drain wall with smear zone for 2D analysis 


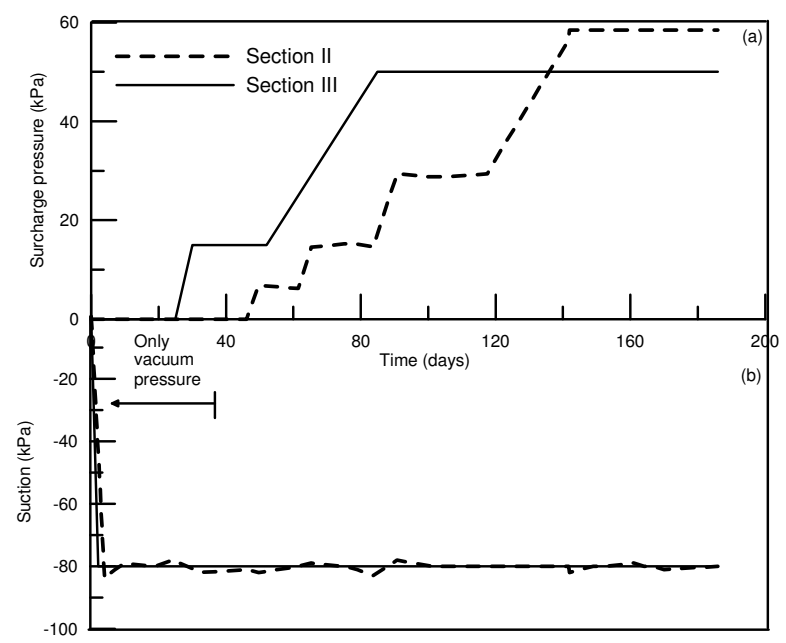

Figure 10 Staged loading history and the measured vacuum pressure 


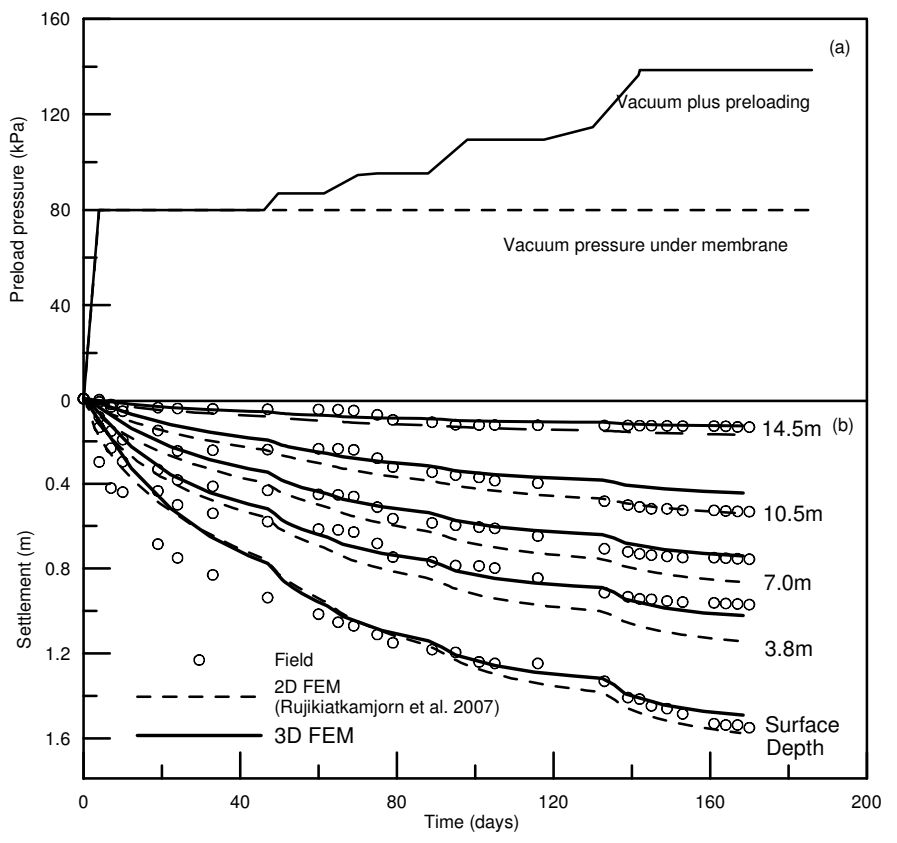

Figure 11 Section II (a) Loading history and (b) Consolidation settlements 


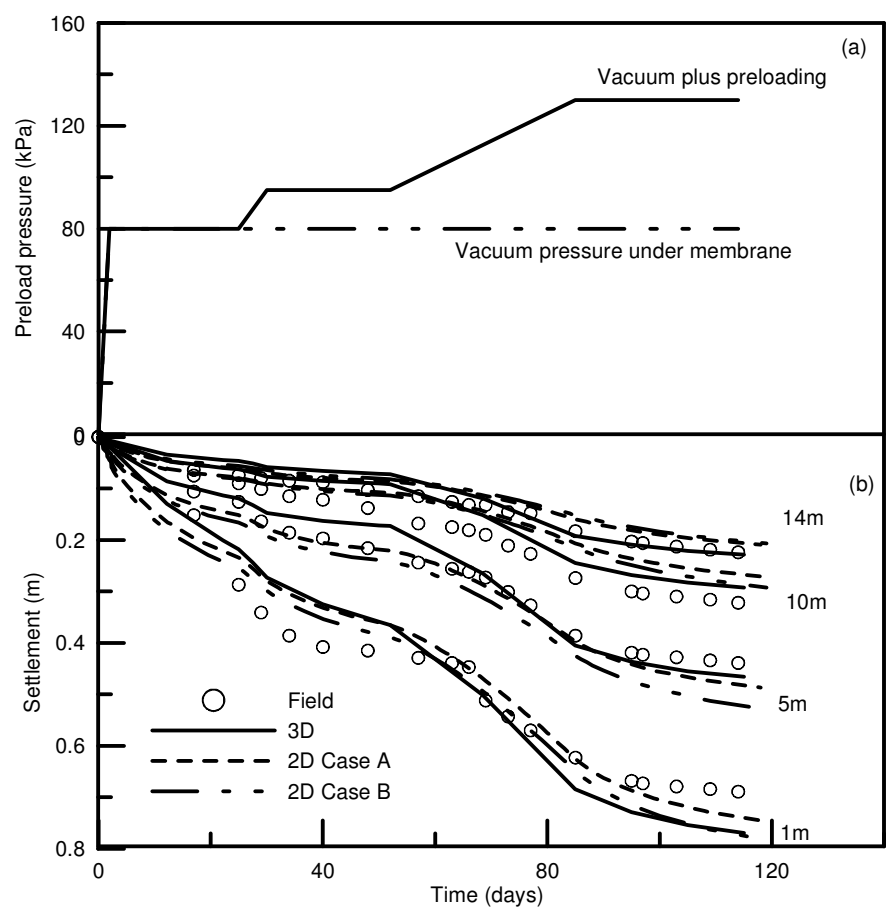

Figure 12 Section III (a) Loading history and (b) Consolidation settlements 


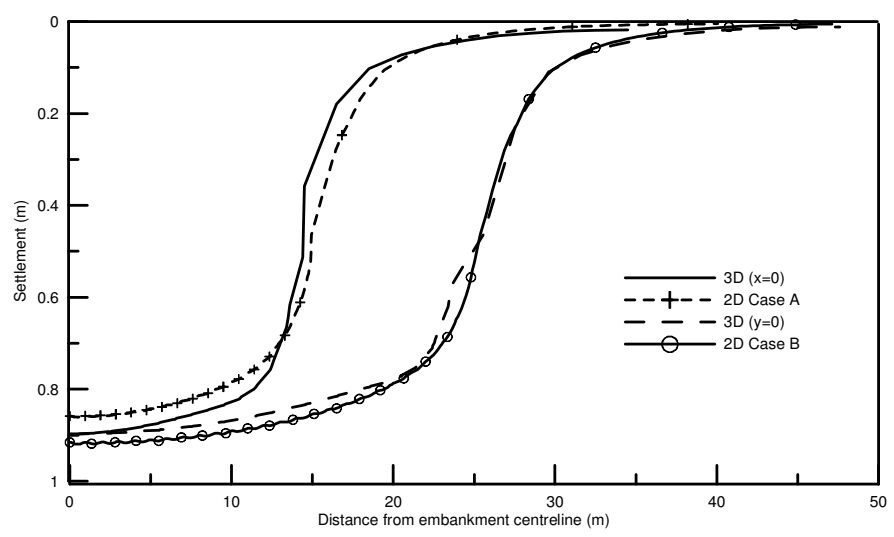

Figure 13 Surface settlement profiles at 180th day (Section III) 


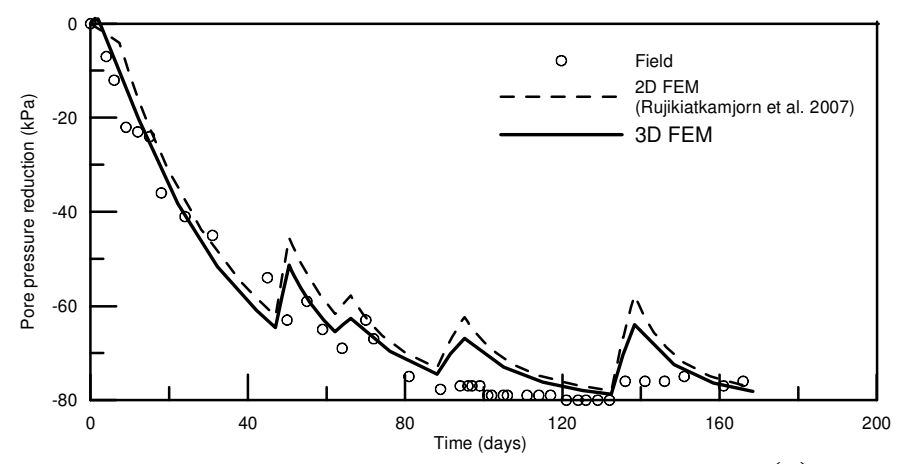

(a)

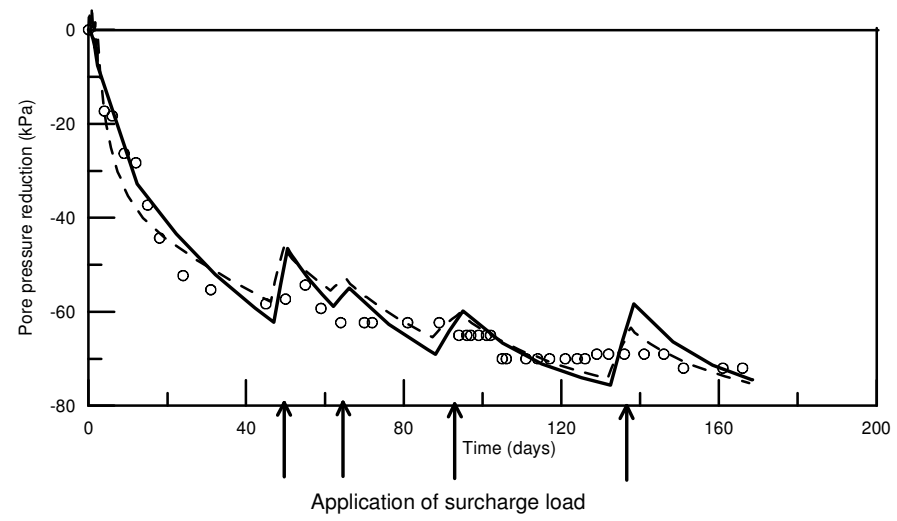

(b)

Figure 14 Pore pressure variation at $0.25 \mathrm{~m}$ away from the embankment centreline (Section II): (a) $5.5 \mathrm{~m}$ depth and (b) $11.0 \mathrm{~m}$ depth (arrows indicate tiems when surcharge loads were applied) 


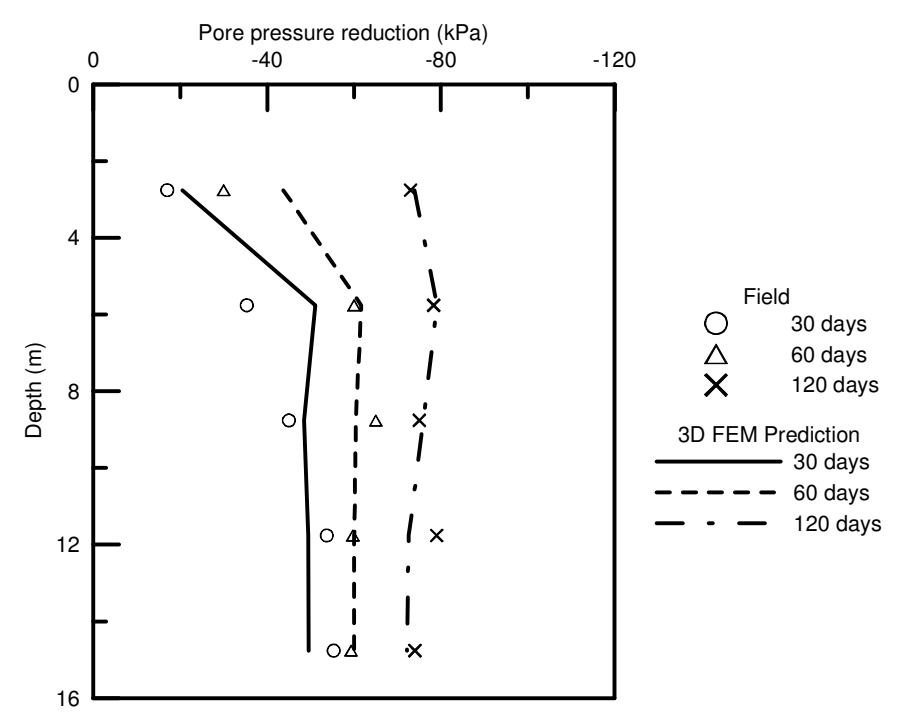

Figure 15 Pore pressure reduction with depth (Section II) 


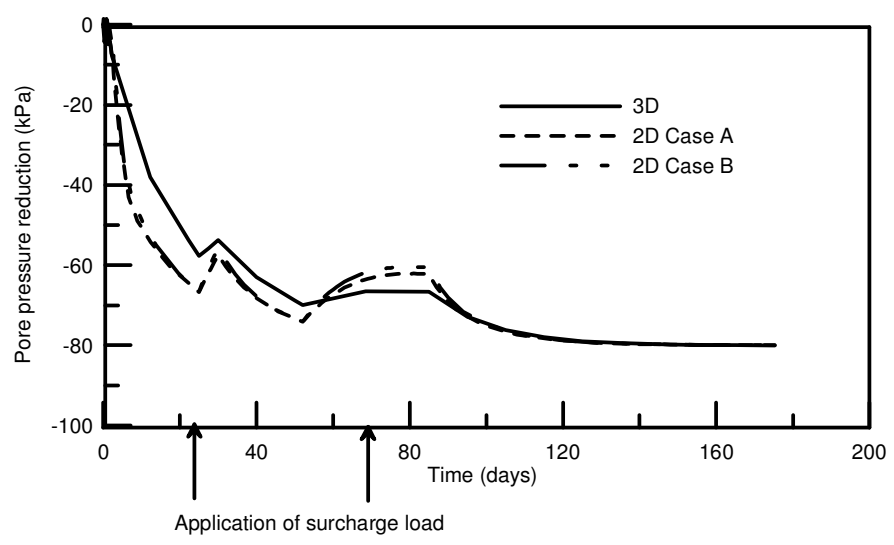

(a)

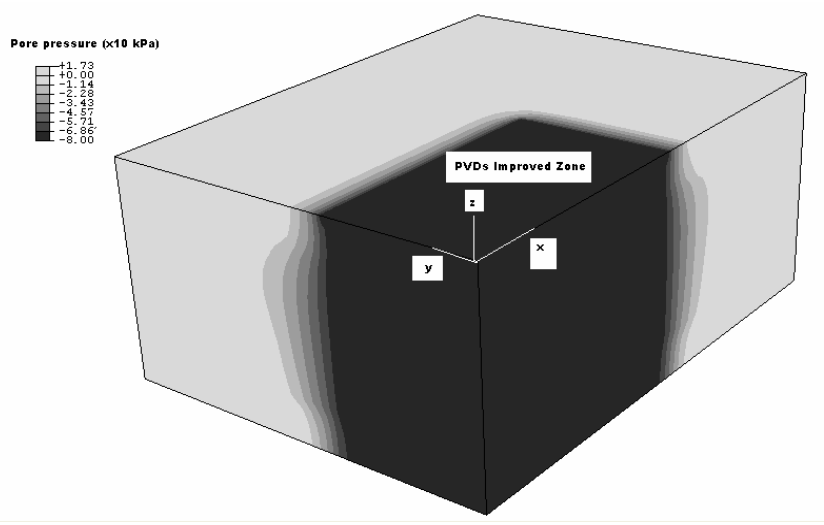

(b)

Figure 16 (a) Pore pressure variation (Section III) at $0.25 \mathrm{~m}$ away from the embankment centreline at $5.5 \mathrm{~m}$ depth (arrows indicate tiems when surcharge loads were applied) (b) Excess pore pressure conturs at $168^{\text {th }}$ day. 


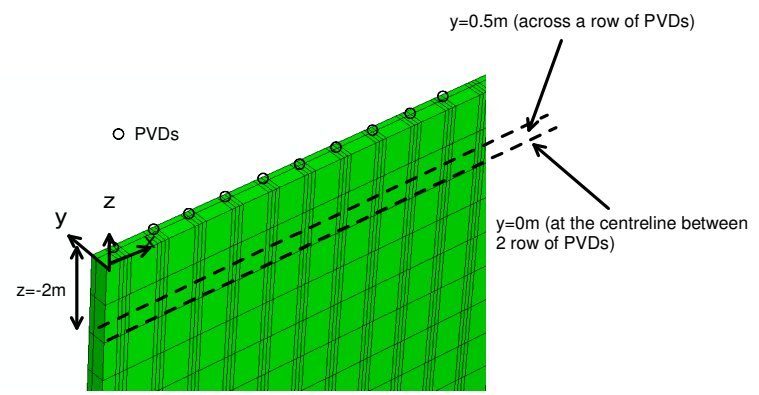

(a)

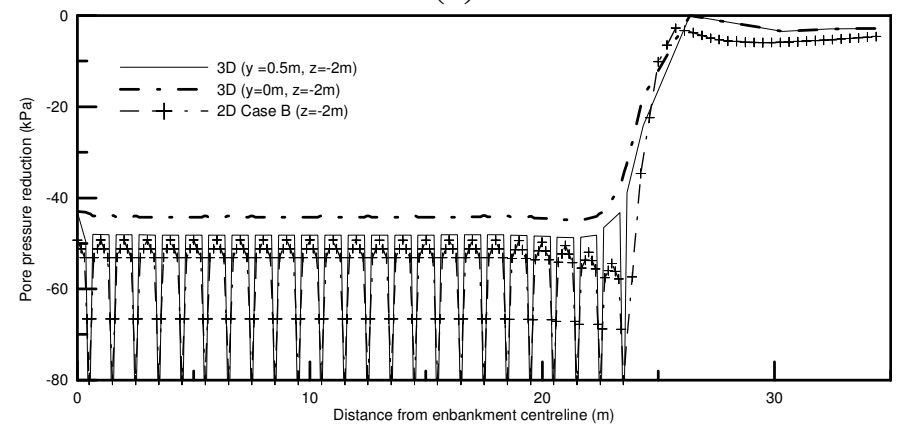

(b)

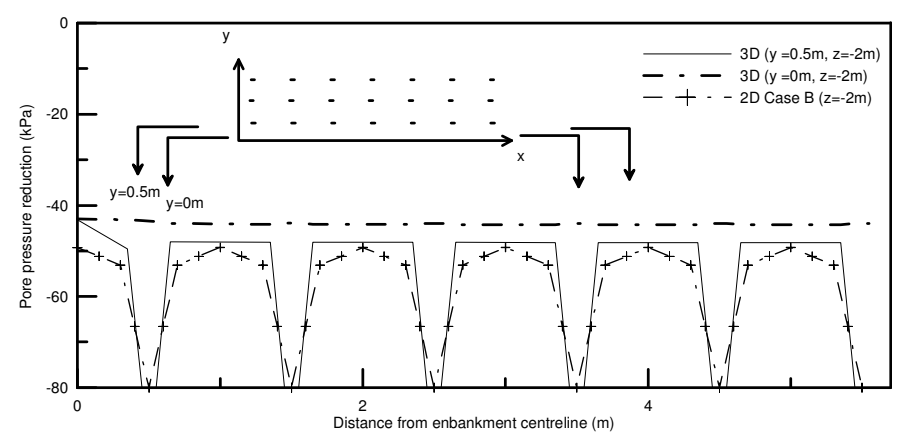

(c)

Figure 17 Distribution of pore pressure reduction (Section III) at 50th day (a) 3D vertical cross-section representing locations of consideration b) $35 \mathrm{~m}$ from the embankment centreline and (c) $5 \mathrm{~m}$ from the embankment centreline 


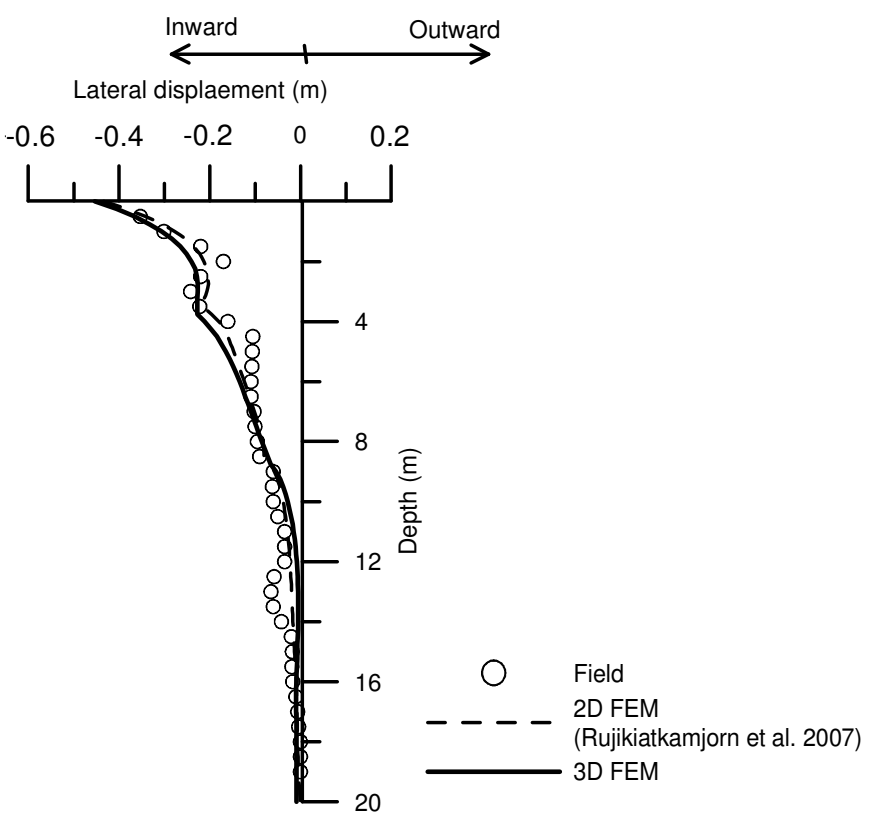

(a)

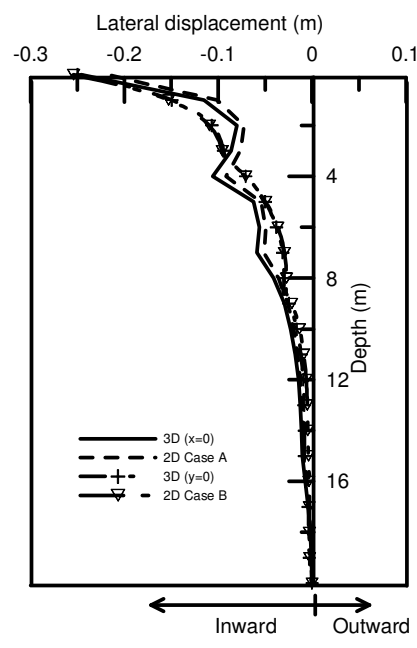

(b)

Figure 18 Lateral displacments at embankment toe (a) Section II at $168^{\text {th }}$ day and (b) Section III at $180^{\text {th }}$ day 


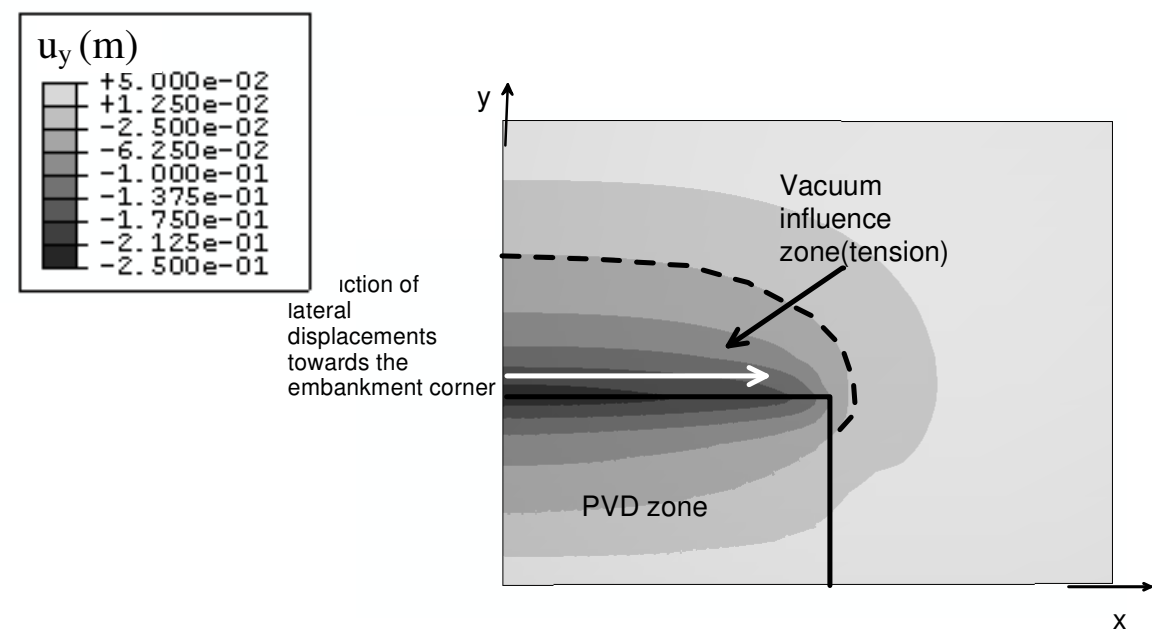

(a)
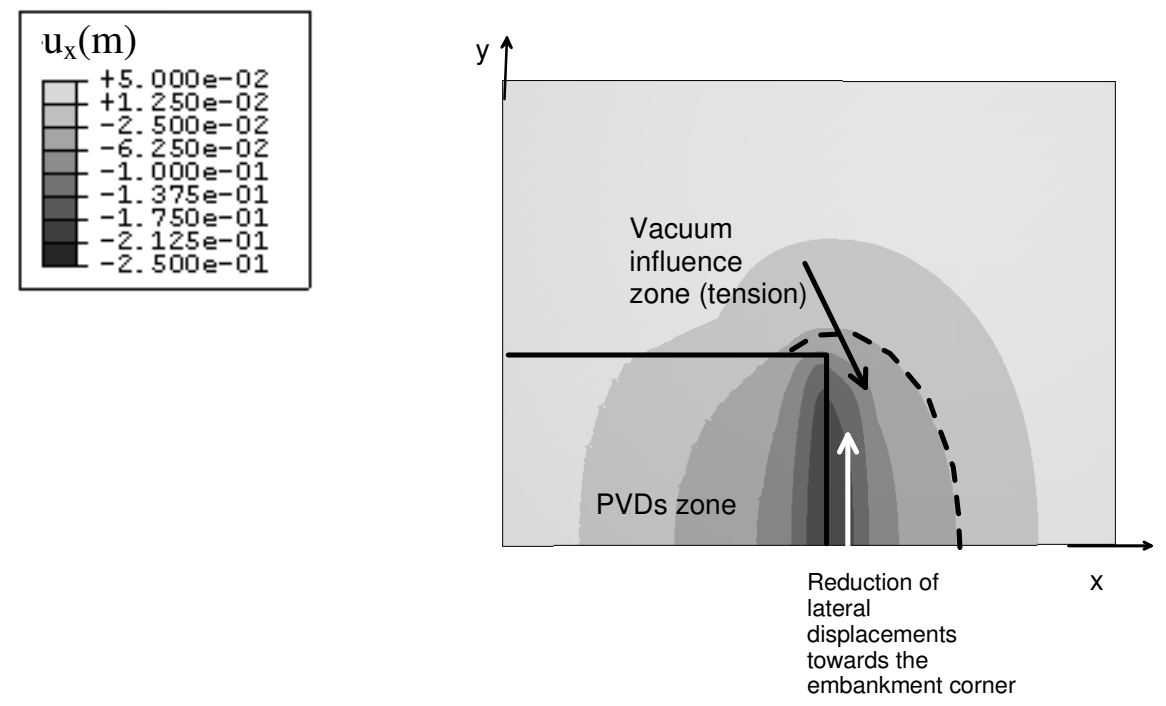

(b)

Figure 19 Surface horizontal displacement contours after 180 days (Section III) (a) horizontal displacement in y direction $\left(\mathrm{u}_{\mathrm{y}}\right)$ and $(\mathrm{b})$ horizontal displacment in $\mathrm{x}$ direction $\left(\mathrm{u}_{\mathrm{x}}\right)$ 